\title{
Assessment of the immune-modulatory activity of sialylated fraction of IVIg in a murine model of allergic asthma
}

\author{
Amir H Massoud ${ }^{1,2^{*}}$, Aidan Ablona', Walid Mourad ${ }^{2}$, Ciriaco Piccirillo ${ }^{3}$, Bruce Mazer $^{1}$ \\ From Canadian Society of Allergy and Clinical Immunology Annual Scientific Meeting 2011 \\ Quebec, Canada. 20-23 October 2011
}

\section{Background}

Intravenous immunoglobulin (IVIg) has potent immunemodulating properties. In OVA-challenged mice, we demonstrated that IVIg markedly attenuates airway hyperresponsiveness (AHR) and abrogates airways inflammation, accompanied by substantial induction of antigen-specific Foxp $3^{+}$Treg from non-Treg precursors.

\section{Methods}

Mice were sensitized (i.n.) with OVA and then received IVIg or sialic acid enriched IVIg (SA-IVIg) fragments (i.p.), and then underwent challenge (i.n.). The induction of $\mathrm{CD} 4^{+} \mathrm{CD} 25^{+} \mathrm{Foxp} 3^{+}$Treg was determined by flowcytometry. AHR was measured, using a flexiVent small animal ventilator. Phenotypic properties of dendritic cells (DC) from various experimental groups were assessed by flow-cytometry. Expression of DCIR on DC was evaluated by flowcytometry and ICC. Adoptive transfer of DC was carried out to show the tolerogenic activity of IVIg-primed DC.

\section{Results}

IVIg and the SA-IVIg fraction induced Treg and abrogated AHR in OVA-challenged mice comparably. It followed by tolerogenic predisposition of DC (decrease of CD80/CD86 expression and IFN $-\gamma$ production and increased level of IL-10). Adoptive transfer of DC from IVIg treated mice to OVA-challenged WT syngeneic mice has the similar antiinflammatory activity of IVIg/SA-IVIg. Expression of DCIR (Inhibitory C-type lectin receptors) on DC of IVIg and SA-IVIg treated mice increased significantly.

${ }^{1}$ Meakins-Christie Laboratories, McGill University, Montreal QC. Canada H2X $2 \mathrm{P} 2$

Full list of author information is available at the end of the article

\section{Conclusions}

IVIg induces Treg likely via conferring tolerogenic activities to DC. This mechanism is dependent on sialylated fraction of IVIg. DCIR is an inhibitory C-type lectin receptor that can be targeted by SA-IVIg and induce an inhibitory signal into the ligated cells. More dissection is required to confirming the role of DCIR in this model.

\section{Author details}

${ }^{1}$ Meakins-Christie Laboratories, McGill University, Montreal QC. Canada H2X 2P2. ${ }^{2}$ Département d'Immunologie et Microbiologie, Université de Montréal, Montreal, QC. Canada H3C 3J7. ${ }^{3}$ Department of Microbiology and Immunology, McGill University Montreal, QC. Canada H3G 1 A4.

Published: 14 November 2011

doi:10.1186/1710-1492-7-S2-A29

Cite this article as: Massoud et al:: Assessment of the immunemodulatory activity of sialylated fraction of IVIg in a murine model of allergic asthma. Allergy, Asthma \& Clinical Immunology 2011 7(Suppl 2):A29.

Submit your next manuscript to BioMed Central and take full advantage of:

- Convenient online submission

- Thorough peer review

- No space constraints or color figure charges

- Immediate publication on acceptance

- Inclusion in PubMed, CAS, Scopus and Google Scholar

- Research which is freely available for redistribution
C Biomed Central

C 2011 Massoud et al; licensee BioMed Central Ltd. This is an open access article distributed under the terms of the Creative Commons Attribution License (http://creativecommons.org/licenses/by/2.0), which permits unrestricted use, distribution, and reproduction in any medium, provided the original work is properly cited. 